\title{
„Moje przodki żyli zdies' kak Poljaki...". Współczesne inskrypcje nagrobkowe cmentarza na Grzywie w Dyneburgu jako przyczynek do rozważań nad kryteriami tożsamości narodowej
}

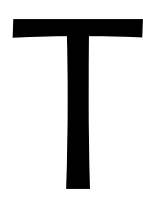

ematem artykułu są inskrypcje nagrobkowe ludności polskiej na przykładzie cmentarza na Grzywie w południowej części Dyneburga'. W materiale badawczym uwzględniłem napisy powstałe od końca lat 80. ubiegłego wieku, kiedy to na Łotwie i w innych republikach ówczesnego ZSRR zniesiono ograniczenia wobec religii i kultu religijnego. Liberalizacja przepisów i obyczajów w Związku Radzieckim szczególnie burzliwy przebieg miała w trzech republikach bałtyckich: na Litwie, Łotwie i w Estonii. Na Łotwie kolejnymi etapami tych przemian było tworzenie od 1988 roku legalnych lub półlegalnych partii i ruchów politycznych, przyjęcie uchwały Łotewskiej Rady Narodowej o samodzielności gospodarczej i ogłoszenie deklaracji o suwerenności kraju (27 i 29 lipca 1989), a przede wszystkim proklamowanie niepodległego państwa łotewskiego (21 sierpnia 1991). Kontakty mieszkańców kraju z Zachodem stały się nowym doświadczeniem w tamtejszej rzeczywistości i zaznaczyły się w stylistyce nagrobków, a być może również w formie napisów nagrobnych. Należy dodać, że burzliwe wydarzenia polityczne związane z rozpadem Związku Radzieckiego i proklamowaniem niepodległego państwa łotewskiego nie znalazły bezpośredniego odbicia w formie nagrobków i inskrypcji. Naturalnym procesem stało się jednak upowszechnienie napisów w języku łotewskim jako państwowym. Inspiracją do podjęcia tematu były pytania o wartość współczesnej epigrafiki cmentarnej jako źródła do badań nad kwestią tożsamości narodowej i religijnej. Czy możliwe jest określenie tożsamości narodowej zmarłego na podstawie inskrypcji nagrobkowych? Jaką rolę spełnia język inskrypcji w przekazie określonych treści o zmarłym i fundatorze nagrobka?

\footnotetext{
1 Dyneburg (łot. Daugavpils) - miasto na Łotwie w południowo-wschodniej części kraju, nad rzeką Dźwiną [łot. Daugava], drugie pod względem liczby mieszkańców. Grzywa (łot. Grīva) to południowe przedmieście Dyneburga, leżące na przeciwnym brzegu Dźwiny, niegdyś samodzielne miasto, przyłączone do Dyneburga w 1953 roku [http://www.daugrc.edu.Iv/Paligmateriali/Citi_mat/Daugavpils/griva.htm].
} 
Od kwietnia do października 2011 roku prowadziłem badania terenowe w powiecie dyneburskim (Daugavpils novads), wielokrotnie odwiedzałem Grzywę. Zgromadziłem dokumentację dotyczącą ponad stu inskrypcji nagrobnych na miejscowym cmentarzu i przeprowadziłem kilkanaście wywiadów na temat obrzędowości pogrzebowej, nagrobków i osób zmarłych ze wskazaniem na kwestie związane z tożsamością narodową (genealogia, język, religia, stosunek do kultury polskiej, relacje między poszczególnymi narodami).

Cmentarz na Grzywie powstał w końcu XIX w. Jest to jeden zwarty kompleks przedzielony lokalną szosą: po jednej stronie cmentarz katolicki, po drugiej cmentarze prawosławny i staroobrzędowy, a od strony północnej niewielka część komunalna założona już po II wojnie światowej, ze znaczną liczbą nagrobków polskojęzycznych. Powierzchnia cmentarza wynosi 14,68 ha. Jest to drugi pod względem obszaru cmentarz w Dyneburgu. Na terenie miasta znajduje się obecnie 12 czynnych lub otoczonych opieką cmentarzy [Lïgums par Daugavpils pilsētas kapu uzturēšanu, 2.01.2007]. Mieszkańcy Grzywy stosują termin „cmentarz”, mówiąc o całym kompleksie, a z odpowiednią przydawką mówią o poszczególnych częściach składowych, np. „,cmentarz ruski”, „,cmentarz starowierów”, „cmentarz katolicki”. Nieliczni starsi mieszkańcy mówią o „cmentarzu polskim”. Groby ludności polskiej w części komunalnej cmentarza nazywane są grobami „po ruskiej stronie” lub „na ruskiej stronie”. Wielu mieszkańców Grzywy mówi „,nasz cmentarz” o kwaterach rodzinnych, liczących kilka do kilkunastu grobów, które otacza niewysoki płotek, granica z kamieni lub żywopłot, po rosyjsku ogradka. Struktura cmentarza stanowi odwzorowanie struktury miejscowości, tak samo topografia grobów jest w jakiejś mierze odbiciem struktury rodowej [Straczuk 2006: 119-121].

Na poszczególnych cmentarzach przetrwał do dziś tradycyjny podział wyznaniowy lub narodowościowy. Na cmentarzu katolickim grzebano ludność polską i łotewską, sporadycznie zmarłych osadników z Ukrainy wyznania greckokatolickiego ${ }^{2}$ oraz luteranów. W latach ZSRR, poza nielicznymi wypadkami, gdy z przyczyn politycznych odmawiano pochówku zmarłego w miejscu zamieszkania, uznawano ten tradycyjny, zwyczajowy porządek, przyjmując kryterium pochodzenia. Osoby niewierzące z rodzin prawosławnych grzebano na cmentarzu prawosławnym, z rodzin katolickich na cmentarzu katolickim [inf. Romuald Poniatowski z Grzywy]. Zmarłym zasłużonym dla Związku Radzieckiego i dla lokalnej społeczności, a zamieszkałym na Grzywie, niekiedy urządzano pogrzeby państwowe na cmentarzu komunalnym w Dyneburgu. Wyraźne przemieszanie narodowościowe nastąpiło po Il wojnie światowej w związku z licznymi małżeństwami mieszanymi, zwłaszcza

2 Na Grzywie po Il wojnie światowej osiedliło się kilkadziesiąt rodzin z Ukrainy; obecnie w parafii zamieszkuje także duchowny obrządku greckokatolickiego, który wspomaga parafie katolickie w okolicach Dyneburga [Gawkowska 2009: 85]. 
polsko-rosyjskimi lub polsko-białoruskimi [Gawkowska 2009: 85-86, por. Jankowiak 2009: 103-105; Straczuk 2006: 121-129]. Pewien wpływ miała również powojenna migracja ludności, głównie z Ukrainy i Białorusi, związana z poszukiwaniem atrakcyjnej pracy zawodowej i lepszych warunków bytowych [por. Jankowiak 2009: 39-40]. Nieliczne groby z napisami w języku polskim pojawiły się w ostatnich latach także na cmentarzu prawosławnym. Ponieważ małżeństwa mieszane były liczne, pojawiło się wiele mogił dwuwyznaniowych, gdzie forma krzyża, a w mniejszym stopniu język, wskazuje na tożsamość zmarłego.

Szukając odpowiedzi na postawione pytania, nie można sugerować się wyłącznie językiem napisu czy postacią imienia i nazwiska zmarłych osób na inskrypcjach. Częstym błędem polskich badaczy, zwłaszcza regionalistów, jest redukowanie kwestii polskości do języka i religii, przez co pomijane są groby Polaków z inskrypcjami w języku rosyjskim lub łotewskim [por. Polskie cmentarze wojskowe 1996; Nekropolie polskie na Łotwie 1996]. Temat polskich inskrypcji nagrobkowych kieruje nas w stronę skomplikowanych relacji narodowościowych w badanej społeczności, wiążących się często z niemożnością rozstrzygnięcia, kto jest, a kto nie jest Polakiem. Na potrzeby tego artykułu stosuję określenia „Polacy”, ,,ludność polska” i ,ludność polskiego pochodzenia”, przy czym ostatnie z nich wskazuje na korzenie i rodowód, ale pozostawia otwartą kwestię obecnej tożsamości lub świadomości narodowej [por. Biesiadowska 2004: 194; Straczuk 2008: 95-96; Kłoskowska 2012: 107-108].

Okolice Dyneburga są w kontekście terytorialnym, ze względu na bliskość Litwy, Białorusi i Rosji, typowym pograniczem. Chodzi jednak nie tylko o kryteria czysto geograficzne, ale również o kontekst kulturowy, nadzwyczaj bogate zróżnicowanie narodowościowe, religijne i językowe. Sąsiadujący z dyneburskim rejon krasławski Mirosław Jankowiak nazwał ,pograniczem pograniczy”, sformułowanie to wydaje się adekwatne również dla badanego regionu [Jankowiak 2009: 11]. Wartościowym przyczynkiem metodologicznym pozwalającym lepiej zrozumieć podejmowany temat są rozważania we wstępie do książki Tożsamość - Język - Rodzina [Engelking, Golachowska, Zielińska 2008: 7-24]. Na obecną sytuację narodowościową regionu złożyło się wielowiekowe dziedzictwo historyczne, zwłaszcza kolonizacja niemiecka, polska i rosyjska, przynależność państwowa i administracyjna w ciągu wieków, represje i ograniczenia wobec niektórych narodów lub wyznań (lub religii w ogólności) ze strony władzy państwowej. Wreszcie działania polityczne i administracyjne kolejnych władz, w tym łotewskich [Rucka 1999: 274-278; Kolbuszewski 1992; Byczkowski 1992]. Dyneburg i Grzywa należały w przeszłości do innych jednostek administracyjnych i odrębnych regionów historyczno-kulturowych. ${ }^{3}$

3 Proces unifikacji zaczął się w 1935 r. dzięki wybudowaniu mostu jedności na Dźwinie (łot. Vienības tilts), decyzją Prezydium Rady Najwyższej ŁSRR w 1953 r. przyłączono Grzywę do Dyneburga, w 1956 r. Zlikwidowano natomiast rejon grzywski (Гривский район) [http://www.daugrc.edu.Iv/Paligmateriali/Citi_mat/Daugavpils/griva.htm]. 
Grzywa do dziś zachowała swój małomiasteczkowy lub wiejski charakter, dominuje tu zabudowa jednorodzinna [Gawkowska 2009: 84-85].

Znajomość polszczyzny mówionej przetrwała u rozmówców głównie w zakresie, jaki przejęli od wstępnych lub jako język kościelny [Ostrówka, Ostrowski, Zielińska 1996: 105-109, Fuszara 2009: 186-190, Gawkowska 2009: 88-91].

Wśród ludzi starszych i średniego pokolenia niezbyt duży oddźwięk miały treści przekazywane w mediach polskojęzycznych, w tym w ukazujących się na Łotwie periodykach i książkach oraz programie radiowym [Ostrówka, Ostrowski, Zielińska 1996: 104; Herman 2009: 165-170]. Jedna z rozmówczyń przyznała: My mówimy tak kak nasze przodki, ale co zapomnieli, to już sie nie wróci [inf. Irena Poniatowska z Grzywy].

Podstawowymi wyznacznikami tożsamości narodowej są dla rozmówców język, religia, pochodzenie rodziców i pragmatyzm narodowościowy. Mniejsze znaczenie przypisuje się zapisom metrykalnym, formie nazwiska czy miejscu urodzenia. Wartość tych kategorii jest zmienna, tak samo jak ich obiektywny lub subiektywny charakter [Jankowiak: 2009, 56-58]. Kryteria językowe nie przesądzają o przynależności do określonego narodu. Częste małżeństwa mieszane między Polakami a Rosjanami sprawiły, że małżonkowie narodowości rosyjskiej opanowali w różnym stopniu również język polski. Rzadko jednak był to w kontaktach wewnątrzrodzinnych język pierwszy i podstawowy. Religia wydaje się najtrwalszym składnikiem tożsamości narodowej [Gawkowska 2009: 90-91, Fuszara 2009: 186-187; Cichomski 2009: 105]. Ważnym elementem tożsamości narodowej jest w badanej społeczności subiektywne odczucie jednostek. Niejednokrotnie pomimo zbliżonej znajomości języka polskiego i podobnego rodowodu rozmówcy różnie określali swoją tożsamość. Jedni mówili, że są Polakami, inni, że płynie w nich polska krew, albo że przodki byli Poljaki. Nawet wśród osób nieznających języka polskiego i nieidentyfikujących się z Polską pojawiały się stwierdzenia w rodzaju: gawarjat, szto my iz Poljakow, daże iz dworjanstwa [inf. Łarisa Maczulska z Grzywy]. Rozmówczyni przyznała, że jej ojciec Jan Maciulski lub Jan Maczulski - w udostępnionych mi dokumentach pojawia się różna pisownia nazwiska - był katolikiem i Polakiem, w latach 1944-1945 jako obywatel radziecki znający język polski służył w Wojsku Polskim. Zawarł małżeństwo z Rosjanką należącą do wspólnoty staroobrzędowców, wszystkie dzieci zostały ochrzczone w religii matki i obecnie identyfikują się z narodowością rosyjską. W kategoriach subiektywnych należy również rozpatrywać pragmatyzm narodowościowy, czyli mniej lub bardziej dobrowolne i świadome identyfikowanie się z określoną narodowością. ${ }^{4}$

${ }^{4}$ W latach ZSRR niektóre osoby narodowości polskiej, osiągając wyższą pozycję zawodową lub dążąc do zrobienia kariery, traktowały czysto pragmatycznie siebie jako Rosjan, dzieci tych osób - czyli drugie pokolenie - często traciły kontakt z polskością. Współcześnie sytuacja się odwróciła: wielojęzyczność zyskała społeczną akceptację, a przyznawanie się do 
Wśród mieszkańców średniego i młodszego pokolenia daje się zauważyć zachwianie tożsamości narodowej. Dość znaczny odsetek mieszkańców nie potrafi określić swojej tożsamości etnicznej lub podkreśla, że należy do dwóch lub nawet trzech narodowości. Dotyczy to przede wszystkim osób pochodzących z małżeństw mieszanych. Zjawisko to trafnie omówiła Antonina Kłoskowska, zalecając konieczność uwzględnienia w badaniach narodowościowych dwóch aspektów zjawiska: identyfikacji narodowej i przyswojenia kulturowego, które nazywa walencją [Kłoskowska 2012: 111-112, 128-129].

Język polski w inskrypcjach stanowi istotną wskazówkę, że przynajmniej jedno z małżonków, najczęściej mąż, było narodowości polskiej lub polskiego pochodzenia. Uwagi badacza nie może ujść fakt, że na omawianym cmentarzu prawie połowa nagrobków ludności polskiej z okresu po II wojnie światowej ma inskrypcje w języku rosyjskim. Nazwiska i imiona o polskim brzmieniu wskazują na polskie pochodzenie [por. Jankowiak 2009: 104-105]. Nierzadko po rozmowie z członkami rodziny zmarłego okazywało się, że poza świadomością polskich korzeni brak jest jakichkolwiek przesłanek do uznania rodziny za polską. Sami rozmówcy, zwłaszcza młodszego pokolenia, identyfikowali się jako Rosjanie, obywatele Łotwy lub sporadycznie jako Łotysze.

W przypadku małżeństw mieszanych powszechnym zwyczajem było grzebanie żony w kwaterze rodzinnej męża. Jeśli żona wyznawała prawosławie, najczęściej przy pochówku we wspólnej mogile umieszczano jej nazwisko w zapisie polskim, o ile inskrypcja małżonka była w tym języku. Wyróżnikiem pochodzenia w tym wypadku był wygrawerowany krzyż prawosławny, rzadziej rosyjskie imię. Identyfikacja wyznaniowa zmarłych wydaje się istotna i ważniejsza niż identyfikacja narodowa czy językowa. Także rodziny nieposługujące się na co dzień językiem polskim w dalszym ciągu grzebią zmarłych w obrządku katolickim [por. Straczuk 2006: 131-133; Jankowiak 2009: 103-105].

Rodzina zmarłego prawie zawsze honorowała wolę zmarłego do określenia jego wyznania. W jakiej wierze zmarły żył, w takiej był grzebany. Jeśli zmarły był ateistą lub osobą niepraktykującą, a pochodził z rodziny religijnej, wtedy zdarzały się odstępstwa od zwyczaju i na grobie umieszczano znak krzyża. Wyznanie, w którym człowiek się urodził, postrzegano jako jego przyrodzoną i niezmienną właściwość [Straczuk 2006: 131-132; por. Kłoskowska 2012]. Kilkakrotnie zdarzyło się, że na grobach zmarłych, którzy bardzo słabo znali język polski i nie czuli się Polakami, umieszczono polskie napisy [inf. Romuald Poniatowski, ks. Antoni Olechno z Grzywy]. Być może język polski (lub tylko alfabet) stał się w konkretnej sytuacji językiem sakralnym, a w konsekwencji graficznym znakiem

pochodzenia polskiego nie utrudnia kariery [por. Kłoskowska 2012: 140-141; Fuszara 2009: 189-190, 197-199]. Młodsze pokolenie mieszkańców Dyneburga traktuje kwestie narodowościowe marginalnie. Na to zjawisko zwrócił uwagę Mariusz Cichomski, nie wskazując jednak wniosków i perspektyw dla dalszych badań [Cichomski 2009: 101-104]. 
identyfikacji wyznaniowej. Język polski byłby więc jedną z cech dystynktywnych, która odróżnia katolików od przedstawicieli innych wyznań [Straczuk 2006: 132-133; Engelking 2011: 155].

Słusznym postulatem będzie więc powiązanie badania inskrypcji nagrobkowych z przeprowadzeniem wywiadów z rodziną zmarłego. Będzie można wówczas bardziej precyzyjnie określić tożsamość narodową i świadomość przynależności do narodu zmarłego, rozmówców i dalszych krewnych, jak również proces kształtowania się tej świadomości. Nagrobki i inskrypcje nagrobkowe wyrażają bowiem nie tylko wolę zmarłego i jego „bagaż” narodowy, religijny i społeczny, lecz przede wszystkim potrzeby i oczekiwania jego rodziny i znajomych. Justyna Straczuk słusznie, na podstawie własnych badań prowadzonych na Białorusi, podkreśliła, że nagrobki nie są wyłącznie dla zmarłych, lecz przede wszystkim dla żywych. Dla rodziny, bliskich i obcych osób, które odwiedzą cmentarz [Straczuk 2006: 130-131].

W ostatnich latach wyraźnie poprawiła się jakość inskrypcji nagrobnych w języku polskim. Teksty są zgodne z normą języka polskiego, najczęstsze błędy dotyczą zastępowania polskich znaków diakrytycznych łotewskimi: š : ś, č : ć, ž : ż, ź, i zamiennego stosowania litery v zamiast w, której nie ma w alfabecie łotewskim. Sporadycznie na inskrypcjach litera łzastępowana jest literą t lub zbliżonym znakiem graficznym, co można tłumaczyć niestarannością kamieniarza lub nieznajomością specyfiki polskiego alfabetu. Pod wpływem języka rosyjskiego powszechnie stawia się na pierwszym miejscu nazwisko przed imieniem, okazjonalnie pojawia się otczestwo. Innym spotykanym zjawiskiem, typowym dla polszczyzny północnokresowej, jest podawanie liczby mnogiej nazwiska według paradygmatu niemęskoosobowego: DROZDOWSKIE / JAN - MARIA [+1995]. Niemal zanikły wahania o : ó, I :ł, s : ś, nierzadkie na starszych napisach. Ze względu na schematyczność i szablonowość inskrypcji, jak również powszechne ograniczenie treści do podstawowych danych metrykalnych, zanikły formy charakterystyczne dla leksyki północnokresowej spotykane jeszcze na nagrobkach z okresu międzywojennego lub wczesnych lat po II wojnie światowej [por. Karaś 2011: 99-101, Straczuk 2006: 131]. Pojawiające się w inskrypcjach błędy ortograficzne lub zapis fonetyczny wynikają - jak przyznają rozmówcy - ze słabej znajomości języka pisanego: TU SPOCZYWA/ KORNILOWICZ / MONIKA / 15081910 - 26101990 / IGNACEGO CURKA.

Nazwisko zmarłego pisane jest na ogół w brzmieniu zgodnym z dokumentami łotewskimi lub polskimi (np. świadectwo chrztu, świadectwo zgonu, dokument tożsamości, Karta Polaka), pisownia imienia podlega zmianom. Może to być wersja archaiczna, jakiej używano w okresie międzywojennym lub wcześniej, zapis fonetyczny lub łotewski: MARIJA, MARYJA, ANASTASIA, STANISLAVA, STANISLAVS, VITOLDS, ZOFJA, LEOKADIJA, 
Artykuły

JOZEFA, APOLONIJA, WŁADISŁAW. Zaledwie na kilku nowszych inskrypcjach podani są fundatorzy nagrobka w formie typowej dla Kresów Wschodnich, np. PAMIĄTKA DZIECI; PAMIĄTKA OD SYNA; PAMIĄTKA OD ŻONY I SYNA [por. Karaś 2011: 104-105]. Zwyczaj ten można częściej spotkać na napisach w języku rosyjskim.

Inskrypcje są nadzwyczaj oszczędne. Powszechne jest podawanie tylko roku urodzin i śmierci, daty dzienne - według moich wyliczeń - pojawiają się na około 60 proc. nagrobków po 1990 roku. Zaledwie kilka inskrypcji w katolickiej części cmentarza zawiera sentencje, wyznanie wiary i prośby, wybrane z pieśni pogrzebowych, np. WIERZĘ W ZMARTWYCHWSTANIE; BOŻE, SĘDZIO SPRAWIEDLIWY, WYNIEŚ WYROK MIŁOŚCIWY; DOBRY JEZU, A NASZ PANIE, DAJ IM WIECZNE SPOCZYWANIE. Sporadycznie pojawia się skrót Ś.P., Ś.†P. lub ŚłP, powszechnym wyznacznikiem przynależności do wspólnoty religijnej jest natomiast grawerowany znak krzyża, łaciński lub prawosławny. Uproszczona forma inskrypcji utrudnia określenie narodowości zmarłego, dlatego konieczne są wywiady z rodziną zmarłego, właścicielami sąsiednich grobów lub przynajmniej z innymi mieszkańcami miejscowości [por. Karaś 2011: 99-101].

Przykładem wspomnianych wątpliwości może być rodzina Drussów. W niedużej kwaterze znajdują się dwa groby z początku naszego wieku. Jeden podwójny: DRUSS / STANISLAVS [1908-1991] - KAPITALINA [1913-1996], drugi syna zmarłych: АРУСС ВАЛЕРИЙ [1946-2008]. Nagrobek rodziców ufundował syn już na początku obecnego stulecia. Żyjący krewni potwierdzili, że ojciec był polskiego pochodzenia, rozumiał język polski, ale na co dzień posługiwał się językiem rosyjskim; zmarły nie czuł szczególnej więzi z Polską ani z Kościołem katolickim, był umiarkowanie pobożny, jak go określono. Miał jednak pełną świadomość, że wywodzi się z rodziny polskiej. Kapitalina Druss była Rosjanką, co potwierdza dodatkowo wygrawerowany powyżej nazwiska krzyż prawosławny. Ich syn czuł się Rosjaninem i jednocześnie deklarował przynależność do Kościoła katolickiego. Żyjący krewni ze strony Drussów są katolikami, uważają się za obywateli Łotwy lub za Rosjan, chociaż jednoznaczne określenie narodowości przychodzi im z trudem.

W liczącej pięć nagrobków kwaterze rodziny Mikuckich także występują inskrypcje w dwóch językach. Najstarszy nagrobek pochodzi z okresu międzywojennego i wykracza poza nasze zainteresowania, natomiast $w$ obrębie ostatnich dziesięciu lat XX wieku z dużą dowolnością użyty został język polski lub rosyjski: Микуцкий / ВИКТОР / ИЗИДОРОВИЧ - 16.III.1940 - 23.XI.1993; TU SPOCZYWA / MIKUCKA / URSZULA / 1911 - 1986 / JZIDOR / 1903 - 1945; МИКУЦКИЙ / РОМУАЛЬА / МИХАЙЛОВИЧ / II 1913 - I 1996; МIКUСКІ / WILHELM / 1937 - 1996 / WANDA / 1944 -. Jeden z mieszkańców Grzywy potwierdził, że rodzina jest katolicka, polskiego pochodzenia i rosyjskojęzyczna. Potomkowie zmarłych słabo znają język polski. Trzy nagrobki wykonał miejscowy kamieniarz samouk, co potwierdza 
nieporadne liternictwo, nagrobek Wilhelma Mikuckiego wykonano natomiast z większą starannością w profesjonalnym zakładzie w Dyneburgu. Już w początkach lat 90. ub. w. zakłady pogrzebowe i firmy kamieniarskie oferowały zleceniodawcom pomoc językową. W przypadku grobów rodziny Mikuckich nie udało się ustalić, czy wybór języka inskrypcji był decyzją zmarłego, czy zleceniodawców nagrobków. Świadomy błąd kamieniarza potwierdził Romuald Poniatowski, mieszkaniec Grzywy. Mimo że zleceniodawca przygotował poprawną wersję, kamieniarz wygrawerował imię zmarłego w błędnej formie „Voicech”. Powinno być „Wojciech” lub poprawnie w języku łotewskim „Voiceh”, co również stanowiłoby dysonans wobec polskiego napisu. W jednej skromnej inskrypcji obserwujemy przenikanie się dwóch odrębnych systemów językowych: RODZINA PONIATOWSKICH / ELEONORA 1924-1996 / VOICECH 1917 -. Mamy tu do czynienia z ciekawym, typowym dla pogranicza zjawiskiem interferencji języków pisanych. Zarówno dla nadawcy, jak i dla odbiorcy treści inskrypcji zmiana języka będzie naturalna, czasami niezauważalna [Straczuk 2006: 139-140].

Inny przykład to rodzina Stroganowów. Brzmienie nazwiska wskazuje na Rosjan, tymczasem współczesny nagrobek ma inskrypcję w języku polskim, również imiona są polskie lub katolickie: STROGANOWY / WŁADISŁAW ANUFRIEWICZ (1914-1995) - MONIKA MICHAlŁOWNA (1914-2004). Nie udało mi się dotrzeć do krewnych, gdyż po śmierci rodziców wyprowadzili się z Grzywy. Sąsiedzi potwierdzają, że byli to Polacy i regularnie praktykujący katolicy. W języku polskim lub tylko w polskiej transkrypcji umieszczono napis na innym nagrobku, gdzie forma imienia i nazwiska wskazywałyby na rosyjskie pochodzenie zmarłego: WLADIMIR ZUKOW [+1999].

Bardzo ważną rolę przy formułowaniu treści inskrypcji odgrywa zleceniodawca. Inaczej nie można wytłumaczyć obecności dwóch lub trzech języków na inskrypcjach w kwaterach rodzinnych lub wśród bliskich krewnych. Bez większych wątpliwości można wytłumaczyć zmianę języka z polskiego na rosyjski lub łotewski w przypadku odległych pokoleń, co odzwierciedlało kulturę domu rodzinnego i było eksplikacją rzeczywistości społeczno-politycznej w danym okresie. Model idealny używanego języka wyglądałby następująco: dziadkowie - język polski, ich dzieci - język rosyjski, wnukowie - język łotewski. Tymczasem na niektórych nagrobkach powstałych w odstępie kilku, nie więcej niż kilkunastu lat, pojawiają się teksty w dwóch lub trzech językach: Bejnarowicz [1987] - Beinarovič [1990, 1996] - Бейнарович [2003]; Truskowski [1987, 1994] - Трусковский [1987]. Kilku rozmówców przyznało, że wybór języka był decyzją osoby lub osób - jeśli decyzja miała charakter kolektywny - które zleciły wykonanie inskrypcji. Tak więc język polski lub łotewski w przypadku cmentarza na Grzywie nie musiał oznaczać, że zmarły posługiwał się nimi w życiu codziennym. 
Badania przeprowadzone w okolicach Dyneburga kierują nas do pytań o kondycję „człowieka pogranicza”. Zgromadzony materiał wskazuje na wielojęzyczność mieszkańców i nadzwyczajną, chociaż niedostrzeganą w pobieżnych kontaktach, ważność kwestii religijnych. Mimo że nie zawsze są dostrzegalne w życiu codziennym, odgrywają istotną rolę w określaniu tożsamości człowieka. Język jako wyznacznik tożsamości narodowej okazuje się kategorią wątpliwą lub przynajmniej nieprecyzyjną. Już na obecnym etapie badań można postawić dwie hipotezy. Po pierwsze, język napisów nagrobnych to przede wszystkim język zleceniodawcy (zleceniodawców), wybrany zgodnie z oczekiwaniami rodziny i lokalnej społeczności, przy tym niekoniecznie język zmarłego. Po drugie, język polski jest w większym stopniu wyznacznikiem tożsamości religijnej niż narodowej. W odniesieniu do Białorusi podobne pytania postawiły Anna Engelking i Justyna Straczuk [por. Engelking 2008: 263-264; Straczuk 2008: 96, 102-103], w okolicach Dyneburga mamy jednak do czynienia z inną i chyba bardziej złożoną sytuacją. Tożsamość narodowa wydaje się zjawiskiem bardziej indywidualnym, osobistym, w przeciwieństwie do tożsamości religijnej, która jest mocno zakorzeniona w rodzinie i w społeczności lokalnej. Na wybór języka inskrypcji składa się co najmniej pięć powiązanych ze sobą elementów: wola zmarłego, świadomość narodowa, językowa i religijna zmarłego, jego rodziny i społeczności lokalnej, wreszcie „moda” na określony styl pogrzebu i upamiętnienia zmarłego. Inskrypcje nagrobne są bez wątpienia cennym i ważnym źródłem do badania tożsamości narodowej i religijnej zmarłego i jego rodziny, ale bez wsparcia w postaci wywiadów, różnorodnych relacji i materiałów genealogicznych mogą prowadzić do błędnych wniosków i zafałszowania uzyskanego w ich efekcie obrazu.

\section{Bibliografia}

http://www.daugrc.edu.Iv/Paligmateriali/Citi_mat/Daugavpils/griva.htm (wejście 18.05.2013). Līgums par Daugavpils pilsētas kapu uzturēšanu, 02.01.2007 [maszynopis udostępniony przez administrację cmentarzy miejskich w Dyneburgu, Labiekārtošana - D].

Biesiadowska Beata, 2004, Культурная и национальная идентификация Польяков в Латвии, „Acta Baltico-Slavica”, XXVIII, s. 193-198.

Byczkowski Janusz, 1992, Z dziejów Polaków na Łotwie w XX w., [w:] Mniejszości polskie i Polonia w ZSRR, red. Hieronim Kubiak, Tadeusz Paleczny, Jarosław Rokicki, Małgorzata Wawrykiewicz, Wrocław - Warszawa - Kraków: Zakład Narodowy im. Ossolińskich, s. 351-361. Cichomski Mariusz, 2009, Młodzi w poszukiwaniu tożsamości, [w:] Polacy nad Dźwiną, red. Jacek Kurczewski, Małgorzata Fuszara, Warszawa: Wydawnictwa Uniwersytetu Warszawskiego, s. 101-122. 
Engelking Anna, Golachowska Ewa, Zielińska Anna, 2008, Tożsamość, język i pamięć w sytuacji pogranicza. Uwagi wprowadzające, [w:] Tożsamość - Język - Rodzina. Z badań nad pograniczem słowiańsko-bałtyckim, red. Anna Engelking, Ewa Golachowska, Anna Zielińska, Warszawa: Slawistyczny Ośrodek Wydawniczy, s. 7-24.

Engelking Anna, 2008, Kim jest „człowiek pogranicza”, [w:] Tożsamość - Język - Rodzina. $Z$ badań nad pograniczem słowiańsko-bałtyckim, red. Anna Engelking, Ewa Golachowska, Anna Zielińska, Warszawa: Slawistyczny Ośrodek Wydawniczy, s. 247-266

Engelking Anna, 2011, Białoruska wieża Babel, czyli mityczne uzasadnienie tożsamości religijnej na pograniczu wyznaniowym. Wersja kołchoźników z Grodzieńszczyzny, [w:] Konstrukcje i destrukcje tożsamości, T. 1: Wokół religii i jej języka, Warszawa: Slawistyczny Ośrodek Wydawniczy, s. 147-164.

Fuszara Małgorzata, 2009, Polacy nad Dźwiną - podobni czy odmienni od Polonii w innych krajach?, [w:] Polacy nad Dźwiną, red. Jacek Kurczewski, Małgorzata Fuszara, Warszawa: Wydawnictwa Uniwersytetu Warszawskiego, s. 177-202.

Gawkowska Aneta, 2009, Polacy w parafiach (głównie rzymskokatolickich) w Daugavpils, [w:] Polacy nad Dźwiną, red. Jacek Kurczewski, Małgorzata Fuszara, Warszawa: Wydawnictwa Uniwersytetu Warszawskiego, s. 83-100.

Herman Aleksandra, 2009, Polsko-łatgalska kultura w Dyneburgu, [w:] Polacy nad Dźwiną, red. Jacek Kurczewski, Małgorzata Fuszara, Warszawa: Wydawnictwa Uniwersytetu Warszawskiego, s. 153-176.

Jankowiak Mirosław, 2009, Gwary białoruskie na Łotwie w rejonie krasławskim. Studium socjolingwistyczne, Warszawa (Język na pograniczach, 37): Slawistyczny Ośrodek Wydawniczy. Karaś Halina, 2011, Uwagi o polskich inskrypcjach nagrobnych na Litwie, [w:] Nekropolie jako znak kultury pogranicza polsko-wschodniosłowiańskiego, red. Feliks Czyżewski, Agnieszka Dudek-Szumigaj, Lubow Frolak, Lublin: Wydawnictwo Uniwersytetu Marii Curie-Skłodowskiej, s. 93-106.

Kłoskowska Antonina, 2012, Kultury narodowe u korzeni, Warszawa: PWN.

Kolbuszewski Jacek, 1992, Polacy na Łotwie. Historia i współczesność. Zarys problematyki, [w:] Mniejszości polskie i Polonia w ZSRR, red. Hieronim Kubiak, Tadeusz Paleczny, Jarosław Rokicki, Małgorzata Wawrykiewicz, Wrocław - Warszawa - Kraków: Zakład Narodowy im. Ossolińskich, s. 331-350.

Nekropolie polskie na Łotwie, 1996, Zeszyty Dokumentacyjne - Ambasada Rzeczypospolitej Polskiej, Cz.1, z. 2-5. Cmentarz św. Michała w Rydze; Ślady polskie na ziemi jełgawskiej; Cmentarz katolicki w Dyneburgu; Ślady polskie w Bukmuiży, red. Jarosław Sozański; oprac. tekstów Janina Głowecka, Jadwiga Radzynia, Halina Szakiel, Ryga: Ambasada Rzeczypospolitej Polskiej w Rydze.

Ostrówka Małgorzata, Ostrowski Norbert, Zielińska Anna, 1996, Współczesna sytuacja językowa Polaków na Łotwie (w okolicach Dyneburga), „Acta Baltico-Slavica”, XXIII, s. 101-111. Polskie cmentarze wojskowe (z lat 1919-1920) na Łotwie. Poḷ karavīru kapi (1919.-1920. g.) Latvijā, 1996, Zeszyty Dokumentacyjne - Ambasada Rzeczypospolitej Polskiej, z.1, red. Jarosław Sozański; tł. na łot. Robert Seliszka, Ryszard Szklennik.

Rucka Iveta, 1991, Sytuacja języka polskiego na Łotwie w latach 1940-1990, „Acta Baltico-Slavica", XXIV, s. 273-294. 
Artykuły

Straczuk Justyna, 2006, Cmentarz i stół. Pogranicze prawosławno-katolickie w Polsce i na Białorusi, Wrocław: Wydawnictwo Uniwersytetu Wrocławskiego.

Straczuk Justyna, 2008, Wielojęzyczność pogranicza. Od tutejszości do nowej lokalności, [w:] Tożsamość - Język - Rodzina. Z badań nad pograniczem słowiańsko-bałtyckim, red. naukowa Anna Engelking, Ewa Golachowska, Anna Zielińska, Warszawa: Slawistyczny Ośrodek Wydawniczy, s. 95-107.

\section{Contemporary tombstone inscriptions in the Griva cemetery in Daugavpils as inspiration for a scientific research on national identity}

The memorial inscriptions found in the Griva cemetery in Daugavpils [Latvia] are a valuable source for scientific research on borderland communities. As well as being a multilingual region the Daugavpils area is characterized by mixed marriages, particularly between people of Polish and Russian origin. The religion of those who have deceased is of the most lasting importance; that which is understood as passed down from generation to generation. The language used in the inscriptions is the result of a complex decision-making process. This takes into account not only religious and national identity but also the will of the deceased, their place of burial and local traditions.

\section{Keywords:}

Latvia, cemetery, national and religious identity, language, borderland

\section{Słowa kluczowe:}

Łotwa, cmentarz, tożsamość narodowa i religijna, język, pogranicze 